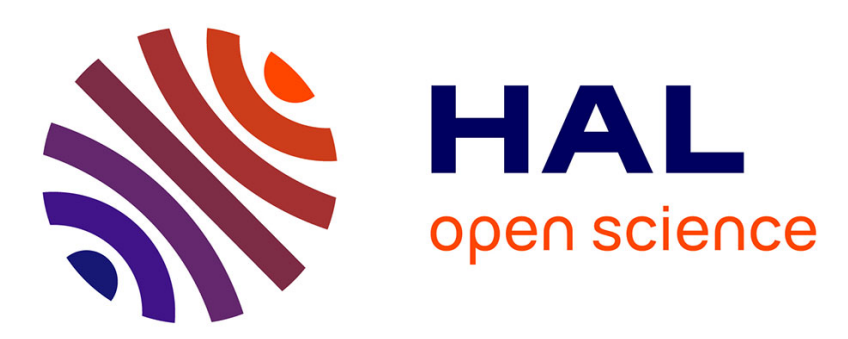

\title{
Annexin A2 expression and partners during epithelial cell differentiation
}

\author{
Malik Zibouche, Françoise Illien, Jesus Ayala-Sanmartin
}

\section{To cite this version:}

Malik Zibouche, Françoise Illien, Jesus Ayala-Sanmartin. Annexin A2 expression and partners during epithelial cell differentiation. Biochemistry and Cell Biology, 2019, 10.1139/bcb-2018-0393 . hal02335473

\section{HAL Id: hal-02335473 \\ https://hal.science/hal-02335473}

Submitted on 28 Oct 2019

HAL is a multi-disciplinary open access archive for the deposit and dissemination of scientific research documents, whether they are published or not. The documents may come from teaching and research institutions in France or abroad, or from public or private research centers.
L'archive ouverte pluridisciplinaire HAL, est destinée au dépôt et à la diffusion de documents scientifiques de niveau recherche, publiés ou non, émanant des établissements d'enseignement et de recherche français ou étrangers, des laboratoires publics ou privés. 
Annexin A2 expression and partners during epithelial cell differentiation

Malik Zibouche, Françoise Illien and Jesus Ayala-Sanmartin*

CNRS, Université Sorbonne, École normale supérieure, Université PSL, Laboratoire des biomolécules, 75005 Paris, France

* Corresponding author: J. Ayala-Sanmartin, CNRS, UMR 7203, Laboratoire des

Biomolécules, 4 Place Jussieu, BP 182, 75252 Paris, France. Tel: 331442732 16. Fax: 331

442771 50. E-mail: jesus.ayala-sanmartin@ sorbonne-universite.fr

\begin{abstract}
The members of the annexin family of calcium- and phospholipid-binding proteins participate in different cellular processes. Annexin A2 binds to S100A10 forming a functional heterotetrameric protein that has been involved in many cellular functions such as exocytosis, endocytosis, cell junction formation and actin cytoskeleton dynamics. Herein, we studied annexin A2 cellular movements and looked for its partners during epithelial cell differentiation. By using immunofluorescence, mass spectrometry and western blot analyses after S100A10 affinity column separation, we identified several annexin A2-S100A10 partner candidates. The association of putative annexin A2-S100A10 partner candidates obtained by MS after column affinity was validated by immunofluorescence and sucrose density gradient separation. The results show that three proteins were clearly associated to AnxA2: E-cadherin, actin and caveolin 1. Overall the data show that annexin A2 is able to associate to molecular complexes containing actin, caveolin 1 and flotillin 2 before epithelial differentiation and to complexes containing E-Cadherin, actin and caveolin 1, but not flotillin 2 after cell differentiation. The results indicate that actin, caveolin 1 and E-cadherin are the principal
\end{abstract}


protein partners of annexin A2 in epithelial cells and that the serine phosphorylation of the $\mathrm{N}$ terminal domain does not play an essential role during epithelial cell differentiation.

Keywords: Actin; Annexin A2; Caveolin; Epithelial cell differentiation; E-cadherin.

\section{Introduction}

The members of the annexin family of calcium- and phospholipid-binding proteins participate in different cellular processes (Gerke and Moss 2002; Rescher and Gerke 2004;

Monastyrskaya et al. 2009). They bind to negative phospholipids of membranes with different $\mathrm{Ca}^{2+}$ sensitivity (Monastyrskaya et al. 2007). Annexin A2 (AnxA2) has been involved in many membrane related processes: exocytosis, endocytosis, cell junction formation and actin cytoskeleton stabilisation and dynamics (Grieve et al. 2012). Two molecules of AnxA2 are able to bind to a S100A10 dimer forming a heterotetramer with high calcium sensitivity for membrane binding. It is accepted that the tetrameric AnxA2 form is functional in cells but functional roles for the monomeric AnxA2 have also been suggested (López-Rodríguez et al. 2018; Taylor et al. 2018).

Actin was described as the first partner of AnxA2. The binding of annexin A2 to actin filaments is calcium dependent (Gerke and Weber 1984) and seems to be mediated by the Cterminal end of the protein (Filipenko and Waisman 2001). AnxA2 not only binds actin filaments but also regulates actin filaments bundling in vitro (Jones et al. 1992; Ma et al. 1994) and in vivo (Falsey et al. 2006). Its role in actin dynamics has been demonstrated during actin-driven macro-pinocytosis rocketing (Merrifield et al. 2001), its accumulation in actin enriched pedestals during bacterial-plasma membrane interaction (Zobiack et al. 2002; Miyahara et al. 2009), and cortical actin remodelling and stress fibres re-arrangements (Hansen et al. 2002; Hayes et al. 2006, 2009; Rescher et al. 2008). The AnxA2 phospholipid ligand phosphatidylinositol-4,5-bisphosphate (PI2P) has been suggested to be a participant of this AnxA2-actin-membrane interactions during membrane ruffles and bacterial pedestals formation (Rescher et al. 2004), and macro-pinocytosis (Hayes et al. 2009).

Caveolin 1 is a protein found in caveolae which are cholesterol-enriched invaginated membrane domains (Murata et al. 1995). Caveolin 1 has been suggested to bind AnxA2 by co-localization in detergent resistant membrane domains (Corvera et al. 2000) and coimmunoprecipitation (Uittenbogaard et al. 2002; Smart et al. 2004). Liao and collaborators 
suggested recently that caveolae are signalling platforms for AnxA2-induced cell proliferation (Liao et al. 2017).

Yamada and collaborators showed that annexin A2 moves from the cytosol to the lateral plasma membrane of epithelial cells and co-localizes with the adherens junction protein Ecadherin (Yamada et al. 2005a). They showed that the inhibition of AnxA2 expression blocks the formation of E-cadherin dependent junctions. In endothelial cells a similar behaviour was observed (Heyraud et al. 2008; Su et al. 2010). Moreover, AnxA2 has been involved in intestinal cell differentiation and polarity (Hein et al. 2011). Interestingly, depletion of cell membrane cholesterol induced AnxA2 membrane dissociation and disruption of adherens junctions (Yamada et al. 2005a; Heyraud et al. 2008). These results suggest that annexin A2 modulates the association of junctional proteins with cholesterol-enriched domains. The involvement of annexin A2 in anchoring structures to the cholesterol-enriched membrane domains was supported by experiments showing that clusters of AnxA2 and CD44 in membrane "rafts" favours the directionality of actin bundles in mammary epithelial cells (Oliferenko et al. 1999).

Annexin A2 can be phosphorylated in residue Tyr23, and it is also phosphorylated by PKC on serine residues in a calcium and phospholipid dependent manner (Johnsson et al. 1986; Khanna et al. 1986) (for review (Grindheim et al. 2017)). Tyrosine phosphorylation of AnxA2 has been involved in the regulation of cofilin-dependent actin cytoskeletal dynamics (Graauw et al. 2008). Jost and Gerke (Jost and Gerke 1996) showed that the principal sites of serine phosphorylation are Ser11 and Ser25 on the AnxA2 N-terminal domain. Moreover, PKC induced phosphorylation has been involved in chromaffin granules membrane fusion (Regnouf et al. 1995) and in mRNA binding (Grindheim et al. 2014). However, the role of AnxA2 phosphorylation during cell junction formation has not been determined.

In this work, we studied AnxA2 movements and looked for its partners during epithelial cell differentiation. The results indicate that actin, caveolin 1 and E-cadherin are the principal partners of annexin A2-S100A10 in epithelial cells and that serine phosphorylation of the Nterminal domain does not strongly affect epithelial differentiation.

\section{Materials and Methods}

\section{Materials}


DMEM with and without $\mathrm{Ca}^{2+}$ and foetal calf serum were from Life Technologies Inc. Rabbit anti human AnxA2 was produced in the laboratory. Mouse monoclonals anti-human S100A10 and anti-flotillin 2, rabbit anti-caveolin 1 and rat monoclonal anti-E-cadherin were from BD biosciences. Goat anti-actin was from Santa Cruz and rat monoclonal anti-ZO1 was a kind gift of M. Maurice (INSERM, CHU Saint Antoine, Paris, France). Secondary antibodies for immuno-fluorescence and WB (anti-mouse, -rabbit and -rat coupled to FITC, CY3 and CY5) were from Jackson ImmunoResearch and Sigma. Restriction enzymes SmaI and T4 polymerase were from Boheringer Mannheim and PpuMI, NheI and T4 DNA ligase from New England Biolabs.

\section{Cell culture}

Madin Darby Canine kidney (MDCK) cells type II provided by Dr. M. Maurice were cultured as described in (Maniti et al. 2012). The cells were grown in Dulbecco's modified Eagle's medium supplemented with $10 \%$ heat-inactivated foetal bovine serum, penicillin $(0.1$ i.u./ml $)$ and streptomycin $(100 \mathrm{mg} / \mathrm{ml})$. MDCK cells were grown at $37^{\circ} \mathrm{C}$ in a $5 \% \mathrm{CO}_{2} /$ air atmosphere. The medium was changed every two days. Caco2 cells were cultured as described in (Ayala-Sanmartin et al. 2004). Briefly the cells were maintained in DMEM supplemented with $20 \%$ heat-inactivated foetal bovine serum, $1 \%$ non-essential amino acids, 0.1 i.u. $/ \mathrm{ml}$ penicillin and $100 \mathrm{mg} / \mathrm{ml}$ streptomycin. Caco 2 cells were grown at $37^{\circ} \mathrm{C}$ in a $10 \%$ $\mathrm{CO}_{2} / \mathrm{air}$ atmosphere. The medium was changed every day.

For calcium-induced differentiation and de-differentiation strategy we followed the protocol described in (Illien et al. 2012). To obtain differentiated epithelial MDCK cells, the cultures were collected 2 days after confluence. Undifferentiated cells were obtained using the $\mathrm{Ca}^{2+}$ depletion strategy (Hansen et al. 2002). Briefly confluent MDCK cultures were incubated in a $\mathrm{Ca}^{2+}$-free medium for two days. This medium was prepared with $\mathrm{Ca}^{2+}$-free DMEM and serum dialyzed against PBS.

\section{Construction and cell transfection of AnxA2-GFP wild type and phosphorylation mutants.}

AnxA2-GFP expression vector pEGFP-C1-AnxA2 was a kind gift of Drs Stephen Moss and Matthew Hayes (University college London, UK) (Merrifield et al. 2001). The N-terminal phosphorylation site mutants of AnxA2-GFP were obtained from the previously constructed pCDNA3 vectors containing the S11A-S25A and S11E-S25E replacements (Ayala-Sanmartin et al. 2000). The restriction fragments containing the mutations were used to replace the wt 
residues of the pEGFP-C1-AnxA2 plasmid. Briefly, the pCDNA vectors containing the annexin A2 phosphorylation mutants were cut with the restriction enzymes SmaI (position 907) and PupMI (position 1778). The resulting 870 bp fragment was purified by agarose gel electrophoresis. The pEGFP-C1-AnxA2 was cut with the restriction enzyme NheI (position 591) and after purification, the sticky ends were filled with the T4 polymerase to be compatible for blunt end ligation with a SmaI fragment. The vector was cut with PpuMI (position 1433) and the fragment containing the vector part of the plasmid was purified by agarose gel electrophoresis. The vector and the mutant containing fragments were ligated (DNA ligase) and the products were transfected in E. coli DH5 $\alpha$ strain by the standard calcium transfection method. The absence of undesired mutations was verified by DNA sequencing. MDCK and Caco2 cells were transfected by the standard lipofectamine (Thermo Fisher) protocol.

\section{S100A10 affinity column.}

S100A10 protein was purified as previously described (Ayala-Sanmartin et al. 2008). Four mg of S100A10 protein were attached to a HiTrap NHS activated HP (Sigma-Aldrich) column (1 ml) as recommended by the furnisher. For control experiments a "void" column was used. The control column was treated and blocked as the S110A10 containing column but in the absence of the protein. Before the cell extract loading, and to avoid unspecific protein binding, the columns were saturated in PBS pH 7 with PVP 1\%. The samples for control and S100A10 affinity columns were prepared as follows. Cells from two Petri dishes $(10 \mathrm{~cm}$ diameter) were lysed in PBS added with protease inhibitors (Sigma Aldrich) cocktail with or without calcium by passing them through needles ( $18 \mathrm{G}, 23 \mathrm{G}$ and $26 \mathrm{G}$ successively). Then the samples were centrifuged $(800 \mathrm{~g})$ for 10 minutes and the supernatant was sonicated and passed through a $45 \mu \mathrm{m}$ filter. Then, the samples were passed through the column in closed circuit overnight in PBS with or without calcium. Columns were washed with PBS buffer and the bound proteins were recovered by elution with Glycine $0.1 \mathrm{M} \mathrm{pH} 2.5$. Elution fractions $(0.5$ ml) were neutralized with Tris $1 \mathrm{M} \mathrm{pH}$ 9. The column was washed with PBS containing sodium azide and conserved at $4^{\circ} \mathrm{C}$.

\section{Immunofluorescence and confocal microscopy.}

Cells were cultured on glass cover-slips in 24 well plates as described in (Illien et al. 2012). The cells were washed with PBS, and fixed with paraformaldehyde (3.7\%) in PBS for 15 minutes at room temperature (Ayala et al. 1989). Then they were washed three times with 
PBS, $\mathrm{NH}_{4} \mathrm{Cl} 50 \mathrm{mM}$ and post-fixed and permeabilized with cold methanol $\left(-20^{\circ} \mathrm{C}\right)$ for 1 minute and washed as before. Fixed cells were saturated with $\mathrm{PBS}, \mathrm{NH}_{4} \mathrm{Cl} 50 \mathrm{mM}$, BSA $1 \%$ for 20 minutes at room temperature. The first antibodies were added at the right dilution during 1.5 hours at room temperature followed by three washes in saturation solution. The secondary antibodies were incubated and washed as the first antibodies. Finally, the coverslips were dried and mounted in Mowiol (Sigma-Aldrich). The fluorescence confocal images were acquired with a TCS SP2 laser-scanning spectral system (Leica, Wetzlar, Germany) attached to a Leica DMR inverted microscope at the specific excitation wavelengths and appropriate emission channels for each fluorophore. Optical sections were recorded with a $63 / 1.4$ or $100 / 1.4$ immersion objectives.

\section{Protein partners identification by mass spectrometry.}

The pull down proteins from S100A10 affinity columns were identified by mass spectrometry. After polyacrylamide gel electrophoresis of column fractions, the coomassie blue-stained bands of interest were cut from gels and processed by trypsin digestion for identification by MS as described (Munera et al. 2012). The proteins were identified by peptide mass fingerprinting using MALDI-TOF-MS. Peptide sequences were obtained by MS/MS. The data was analysed by using the MASCOT search algorithm. Molecular weight search (MOWSE) scores attained for individual protein identifications were inspected manually and considered significant only if at least two peptides were matched for each protein. The MS identification was performed for two independent extracts and for each cell type and differentiation state (differentiated and undifferentiated).

\section{Sucrose density gradients.}

Sucrose solutions at 20\% and 50\% (W/V) were prepared in buffer Hepes $40 \mathrm{mM} \mathrm{pH} \mathrm{7,} \mathrm{KCl}$ $30 \mathrm{mM}$ EGTA $1 \mathrm{mM}$, and free $\mathrm{Ca}^{2+} 0.2 \mathrm{mM}$. The gradients were prepared in $12 \mathrm{ml}$ polypropylene Beckman tubes with a mixer (Amersham) and the help of a peristaltic pump. The cell extracts were laid on the top of the gradients and centrifuged $35000 \mathrm{~g}$ during 16 hours at $4^{\circ} \mathrm{C}$ in a Beckman rotor SW41.Ti. 24 fractions $(0.5 \mathrm{ml})$ were collected. The refraction index of all fractions was measured with a refractometer and their density was calculated with a reference table (Evans 1978).

\section{Miscellaneous procedures.}


Standard protein quantification, gel electrophoresis and western blot were performed as described in (Borot et al. 2009). DNA purification for AnxA2-GFP mutants construction and transfections was performed as described previously (Ayala-Sanmartin and GomezEichelmann 1989). The statistical analysis; unpaired, two-tailed t-test was performed with GraphPad Prism software.

\section{Results}

\section{Annexin A2 expression before and after epithelial cell differentiation.}

To characterise AnxA2 expression in epithelial cells, we performed cell cultures of MDCK cells (kidney) and Caco2 cells (intestinal epithelium). We plated 50000 dissociated MDCK cells or $100000 \mathrm{Caco} 2$ cells in $60 \mathrm{~mm}$ Petri dishes and recovered the cultures after 2, 4, 6, 8 and 10 days for MDCK and after 3, 7, 11, 16 and 21 days for Caco 2 cells. The cells were lysed and the protein content was quantified by BCA. Fig 1A shows that MDCK cell line arrive at confluence on day 6 and Caco2 cells at day 11. Microscopy observation showed that at day 2 (and 3) the cultures showed small cell aggregates, at day 4 (and 7) the cultures were close to confluence and at day 6 (and 11) they were fully confluent (data not shown).

Specific protein expression was analysed by western blot. Fig 1 shows that AnxA2 and S100A10 expression increases slightly during in vitro epithelial cell differentiation. However, S100A10 expression increase was not statistically significant in MDCK cells.

Cellular localization of AnxA2 and its principal partner S100A10 were followed by immunofluorescence and confocal microscopy. Fig S1 shows a strong co-localization of both proteins in MDCK cells during all steps of epithelial differentiation. However, in fully differentiated cells, we observed an enrichment in AnxA2 in the apical pole of the cells and that both proteins co-localize approaching the apical region. In the basolateral region, annexin A2 was probably present also in monomeric form because S100A10 showed low expression in this zone (Fig S1).

\section{Annexin A2 co-localizes with E-cadherin in adherent junctions}

Yamada and collaborators have shown that AnxA2 was involved in adherens junctions formation (Yamada et al. 2005a). Therefore we followed its localization during MDCK cellcell contacts formation. We plated dissociated MDCK cells at different cell densities (2 000 to 30000 cells per well) and fixed them four days later. Fig 2A shows clear co-localization of 
AnxA2 with E-cadherin at the level of early cell contacts as well as in cells highly confluent and differentiated (Fig S2A). Lee and collaborators reported that AnxA2 co-localized with tight junctions in a MDCK II cell line (Lee et al. 2004). However, we saw no localization with the marker of tight junctions ZO1 during in vitro cell differentiation (Fig 2B and S3). The ZO1 signal was very thin and close to the membrane zones enriched in AnxA2 but not in contact with them.

To study the distribution of annexin A2, S100A10 and E-Cadherin, we performed triple antibody labelling. As shown in Fig 2C and S2B, the previously observed co-localization of AnxA2 with E-cadherin was confirmed and the co-localization of S100A10 with both proteins were evidenced suggesting that AnxA2 is in the heterotetrameric form.

\section{Expression of AnxA2-GFP during epithelial cell differentiation.}

An MDCK cell line expressing the chimeric protein AnxA2-GFP was obtained. The expression level of the AnxA2-GFP chimeric protein was evaluated. Cell extracts were subjected to an affinity column containing the S100A10. Western blot revealed that the expression of AnxA2-GFP chimeric protein was 35\% and the endogenous protein of $65 \%$ (Fig S4A). This fact rise the possibility that the total annexin A2 content in the transfected cells would be higher compared to the wild type cells. However it is also possible that the cell regulates the expression of the endogenous protein in order to maintain normal total annexin A2 levels. To characterize the AnxA2-GFP calcium dependent movement to the membranes we treated the cells with the calcium ionophore ionomycin. After 10 minutes of ionophore addition, the association of the protein with the plasma membrane due to the calcium entry into the cells was clearly observed (Fig S4B), as previously reported with other pore forming peptides (Lamaziere et al. 2007). We also obtained a Caco2 cell line expressing AnxA2-GFP. The chimeric protein presented a similar behaviour during epithelial cell differentiation compared to MDCK cells and showed strong co-localization with S100A10 (Fig S5).

We followed the expression of AnxA2-GFP, S100A10 and E-cadherin by confocal microscopy and observed co-localization of AnxA2-GFP with S100A10 and E-cadherin during junction formation and in differentiated cells (Fig 3).

\section{Annexin A2 localization during differentiation and de-differentiation of MDCK cells.}

In order to obtain a high quantity of cells in the undifferentiated state, we performed cell cultures at a high density in the absence of calcium by using the calcium switch protocol. We 
characterized the cellular movements of AnxA2, S100A10 and E-cadherin during differentiation and de-differentiation. As shown in Fig S6, the undifferentiated cells express the 3 proteins mainly in the cytosol. After addition of calcium the cellular junctions established and the three proteins move from the cytosol to the plasma membrane at the level of cell-cell contacts. Co-localization of AnxA2 with S100A10 and E-cadherin was observed.

\section{Annexin A2-S100A10 partners in differentiated and undifferentiated Cells.}

To find out AnxA2 partners in MDCK and Caco2 cell lines, we used a S100A10 affinity column. The elution fractions were collected and subjected to gel electrophoresis. To confirm the S100A10 binding specificity of the pull down proteins, we compared the bands with those of a control (void) column. Figure S7 show several examples of gels indicating that the S100A10 column specifically pull down S100A10 and AnxA2 binding proteins. After gel electrophoresis we identify the bands of interest by mass spectrometry. Two independent experiments were performed for each cell line. Several annexin A2-S100A10 partner candidates were identified. The proteins identified with the best scores were $\beta$-actin, heat shock 70 cognate protein (HSC70) and $\alpha$-Enolase 1 from MDCK cells, and $\beta$-actin, $\beta$-tubulin and $\alpha$-Enolase 1 from Caco 2 cells.

The partner candidates from the affinity column were verified by western blot. Three independent experiments were performed. As shown in Fig 4, actin was detected as a S100A10-AnxA2 partner in differentiated and undifferentiated cells. We were unable to detect HSC70, Enolase 1 and tubulin by western blot. On the contrary, caveolin 1 and flotillin 2, two proteins which are, similarly to AnxA2, associated to cholesterol enriched membrane domains, were pulled down with the S100A10 affinity column. Caveolin 1 was detected in differentiated and undifferentiated cells and flotillin 2 only in undifferentiated cells.

We also performed a study of protein co-migration in sucrose density gradients. As shown in Fig 5, in undifferentiated cells, AnxA2 and S100A10 were found in high quantity in fractions of density 1.09 and 1.17 and in minor quantity in fraction of density 1.15 . The actin and AnxA2 profiles were very similar. E-cadherin was found in fraction 1.17, 1.15 and 1.09. On the contrary, flotillin 2 was present mainly in the 1.17 fraction and caveolin 1 was present in fractions of density from1.11 to 1.16. After cell differentiation, we observed that AnxA2 in the 1.09 and 1.17 fractions diminished but its amount increased in fraction 1.13 giving a plateau 1.13 to 1.19 . S100A10 was present in fractions $1.08,1.15 .1 .17$ but was absent in the 1.13 fraction. The actin profile was similar to that of AnxA2 and E-cadherin was also 
enriched in the zone 1.11 to 1.19 . Flotillin 2 (1.17) and caveolin 1 (1.13 to 1.17$)$ show only small changes in density profile after cell differentiation. Overall, the data show that actin and E-cadherin co-migrate with AnxA2 before and after cell differentiation. On the contrary after cell differentiation, the degree of co-migration of AnxA2 and caveolin 1 strongly increases. Flotillin 2 seemed not to be sensitive to cell differentiation and AnxA2 movements.

\section{Cellular localisation of Annexin A2-S100A10 partners candidates.}

Immunofluorescence experiments were performed to characterize the localization of AnxA2 partner candidates during epithelial cell differentiation. In MDCK cells, no clear colocalization with tubulin was observed. HSC70 does not co-localizes with AnxA2 in membranes involved in cell-cell contacts and only small co-localization was observed in peripheral membranes of undifferentiated cells (Fig S8A). On the contrary we observed clear co-localization of caveolin 1 with AnxA2 and S100A10 (Fig 6) in the cell-cell contact zones. We also performed cellular localization experiments with the AnxA2-GFP cell line. As for wild type MDCK cells, we did not observe localization of AnxA2 with tubulin (Fig S8B). On the contrary, we observed co-localization with S100A10, actin, caveolin 1 and E-cadherin (Fig 7).

In order to study the role of serine phosphorylation on the N-terminal domain of AnxA2, we constructed chimeric AnxA2-GFP double mutants on serine residues 11 and 25. We replaced serine by alanine residues to avoid phosphorylation (S11A-S25A) and by glutamic acid residues to mimic "permanent phosphorylation" (S11E-S25E). The physicochemical characterisation of the mutants showed that they are able to bound S100A10 in vitro (AyalaSanmartin et al. 2000). Fig 8 shows that the mutants did not perturbed the formation of junctions neither the co-localization of AnxA2-GFP with E-cadherin, actin and caveolin 1.

\section{Discussion}

In the present paper we studied the localisation of AnxA2, S100A10 and its putative partners during epithelial differentiation of kidney and intestinal cells lines in vitro. MDCK and Caco2 cell lines changed their morphology and underwent full polarization showing formation of adherens and tight junctions and reorientation of cytoskeletal elements (Bacallao et al. 1989). We searched for annexin A2-S100A10 partner proteins during epithelial cell differentiation by analysing the AnxA2 binding proteins in cells before and after cell differentiation. By 
using immunofluorescence, mass spectrometry and western blot analyses after S100A10 affinity column separation, we had identified several AnxA2 partner candidates. We also performed co-immunoprecipitation experiments but unfortunately without success. Probably because the interaction of annexin A2 with membranes and partners diminish the availability of annexin A2 surface for antibody recognition. We also performed protein crosslinking of cell extracts before column affinity pull down but it was also difficult to obtain accurate MS data. The putative partner candidates detected after S100A10 affinity column can be considered as partners of the tetrameric form of the protein (Annexin A2-S100A10) because in the column, the most important protein associated to S100A10 is AnxA2 (Fig S7). The association of some putative candidates obtained by MS after column affinity such as the $\alpha$ enolase-1, the chaperon protein HSC70 and tubulin were not validated by other techniques such as immunofluorescence and sucrose gradient separation. However, it have been reported that enolase-1 is present in caveolae and co-precipitates with Cav-1 and AnxA2 (Zakrzewicz et al. 2014). These data support the interaction observed herein by affinity pull-down. Three proteins were clearly associated to AnxA2: E-cadherin, actin and caveolin 1.

Cell junctions are very complex structures (Vogelmann and Nelson 2004). The adherens junctions are calcium-dependent molecular complexes necessary for epithelial cell differentiation. The role of AnxA2 during cadherin junctions formation has been demonstrated in epithelial and endothelial cells (Yamada et al. 2005a; Heyraud et al. 2008). The E-cadherin protein associates to catenins that bind the actin cytoskeleton. It has been suggested that the adherens complex is modulated by the sphingomyelin cholesterol-enriched domains in the membranes (Bryant and Stow 2004). Herein, we observed by immunolocalisation and membrane separation by sucrose density gradients that AnxA2 and Ecadherin are associated during the adherens junction formation in kidney (MDCK) and intestinal (Caco2) cells. However, we were unable to detect E-cadherin in affinity columns suggesting that the association of AnxA2 with cadherin could be mediated by other proteins or lipids in the junctional zone.

The actin-AnxA2 binding has been well documented (for reviews see (Hayes et al. 2004; Grieve et al. 2012)). In the present work we found an association of annexin A2 and actin by affinity column and corroborate this association by immunofluorescence and sucrose density gradients. The association of annexin A2 with E-cadherin could be mediated by actin. However the direct association of actin with E-cadherin has been questioned by experiments which demonstrated that catenins, are not associated to actin and cadherin at the same time 
(Drees et al. 2005; Yamada et al. 2005b). In such a case, another molecule could be responsible for the association with the junctional complex. This partner could be a protein but we did not exclude that the lipids in the form of particular membrane domains enriched in cholesterol, phosphatidylserine or PI2P play an important role in this process.

Caveolin 1 was the third identified partner. This protein is considered to be present in cholesterol enriched membrane domains (Murata et al. 1995; Harder and Simons 1997) and has been shown to co-localize with AnxA2 (Corvera et al. 2000; Uittenbogaard et al. 2002; Liao et al. 2017). In spite of the fact that a study concerning the interaction of cav-1 and annexin A2 has been retracted (Smart et al. 2004), three other reports and our own study demonstrate a relationship between both proteins. In endothelial cells caveolin 1 and AnxA2 bound to low density cholesterol-enriched membranes after formation of cellular junctions (Corvera et al. 2000). Moreover, it is known that the presence of cholesterol in membranes increases the calcium sensitivity for AnxA2 membrane binding (Ayala-Sanmartin 2001; Ayala-Sanmartin et al. 2001). Therefore, the Caveolin-AnxA2 association seems to depend on membrane lipid composition.

Overall the data shows that annexin A2-S100A10 is able to associate to molecular complexes containing actin, caveolin 1 and flotillin 2 before epithelial differentiation and to complexes containing E-Cadherin, actin and caveolin 1, but not flotillin 2 after cell differentiation. It is of interest to note that after cell differentiation, AnxA2 and other proteins move to compartments of light density and that the increase of cholesterol at the level of the plasma membrane could be responsible for this change in density. At present we know that annexin A2 can bind actin but it is less clear whether the association with the other proteins is directly or indirectly mediated by other proteins or membrane domains. Considering that AnxA2 is essentially a membrane phospholipid binding protein sensitive to cholesterol content, we must consider the membrane domains as mediators of these complex interactions. In fact, it has been shown that membrane clusters of AnxA2 and CD44 depend on cholesterol and favour the direction of actin bundles to these membrane domains (Oliferenko et al. 1999). It is of interest to note that there is a correlation between the actin filament membrane attachment and plasma membrane ordered domain formation (Dinic et al. 2013). In smooth muscle cells, a membrane domain separation of stiff actin binding and flexible caveolar domains that bind annexin proteins at different calcium concentrations have been observed (Babiychuk and Draeger 2000). A similar behaviour could be present in epithelial cells in which AnxA2 bind to different membrane domains (caveolar, actin rich cell junctions) at different calcium concentrations 
and/or with different membrane phospholipids. For example, PI2P which is a ligand of AnxA2, is involved also in actin filaments reorganisation and changes in cell shape (Takenawa and Itoh 2001). Martin-Belmonte and collaborators showed that annexin A2 expression in the apical surface of MDCK cells overlapped with actin and suggest that this is an important event during the establishment of apical membrane identity (Martin-Belmonte et al. 2007). Moreover, AnxA2 is targeted to PI2P sites of the membrane enriched in cholesterol where actin accumulates (Rescher et al. 2004; Gokhale et al. 2005) and the localisation of AnxA2 to cell-cell contacts and actin re-organisation seemed to require PI-3 kinase activity suggesting the participation of lipids and not only proteins in these complex cellular processes (Hansen et al. 2002). Secondly, membrane cholesterol seems to play an important role because its decrease abolished both, the AnxA2 movement to the membrane and the concentration of E-cadherin to the nectin cell-cell contact sites (Yamada et al. 2005a; Heyraud et al. 2008).

In the present study we were unable to observe differences in behaviour and localisation of annexin A2 serine phosphorylation mutants. However, other studies showed that Tyrosine phosphorylation is an important event in actin mediated changes in cell morphology associated with the control of cell adhesion in BHK cells (Rescher et al. 2008) and in nicotine induced chromaffin cell secretion (Gabel et al. 2019). New experiments designed to study the dynamics of serine phosphorylation-dephosphorylation must be performed to deeply investigate the role of annexin A2 serine phosphorylation during epithelial cell differentiation. In conclusion, the association of AnxA2 with other proteins and lipids is a very complex field to be developed accurately. The participation of AnxA2 in different cellular processes seems to be mediated by different proteins but, the association with the membranes lipids organized in different domains play certainly a very important role. Therefore, the development of new experimental approaches such as lipidomics of Annexin A2 membrane binding sites must be considered in the future research.

\section{Acknowledgments}

Dr Stephen Moss and Dr Matt Hayes (University college London, UK) for AnxA2-GFP expression vector. Dr Michelle Maurice (INSERM, CHU Saint Antoine, Paris, France) for ZO1 antibody and MDCK cells. Drs Christelle Lenoir and JL Delaunay (CHU Saint Antoine, 
INSERM, France) for helping with AnxA2-GFP cloning in MDCK and Caco2 cells. Anne

Marie Juniaux (INSERM, France) for technical assistance.

\section{References}

Ayala, J., Olofsson, B., Tavitian, A., and Prochiantz, A. 1989. Developmental and regional regulation of rab3: a new brain specific "ras-like" gene. J Neurosci Res 22(3): 241-6.

Ayala-Sanmartin, J. 2001. Cholesterol enhances phospholipid binding and aggregation of annexins by their core domain. Biochem Biophys Res Commun 283(1): 72-9.

Ayala-Sanmartin, J., Cavusoglu, N., Masliah, J., and Trugnan, G. 2004. Homodimerization of Annexin 2. Role of the N-terminal tail and modulation of membrane aggregation properties. Annexins 1(1): 19-25.

Ayala-Sanmartin, J., and Gomez-Eichelmann, M.C. 1989. Stability of ColE1-like and pBR322-like plasmids in Escherichia coli. Mol Microbiol 3(12): 1745-52.

Ayala-Sanmartin, J., Gouache, P., and Henry, J.P. 2000. N-Terminal Domain of Annexin 2 Regulates $\mathrm{Ca}(2+)$-Dependent Membrane Aggregation by the Core Domain: A Site Directed Mutagenesis Study. Biochemistry 39(49): 15190-15198.

Ayala-Sanmartin, J., Henry, J., and Pradel, L. 2001. Cholesterol regulates membrane binding and aggregation by annexin 2 at submicromolar $\mathrm{Ca}(2+)$ concentration. Biochim Biophys Acta 1510(1-2): 18-28.

Ayala-Sanmartin, J., Zibouche, M., Illien, F., Vincent, M., and Gallay, J. 2008. Insight into the location and dynamics of the annexin A2 N-terminal domain during $\mathrm{Ca}(2+)$-induced membrane bridging. Biochim Biophys Acta 1778(2): 472-82.

Babiychuk, E.B., and Draeger, A. 2000. Annexins in cell membrane dynamics. Ca(2+)-regulated association of lipid microdomains. J Cell Biol 150(5): 1113-24.

Bacallao, R., Antony, C., Dotti, C., Karsenti, E., Stelzer, E.H., and Simons, K. 1989. The subcellular organization of Madin-Darby canine kidney cells during the formation of a polarized epithelium. The Journal of Cell Biology 109(6): 2817-2832. doi:10.1083/jcb.109.6.2817.

Borot, F., Vieu, D.L., Faure, G., Fritsch, J., Colas, J., Moriceau, S., Baudouin-Legros, M., Brouillard, F., Ayala-Sanmartin, J., Touqui, L., Chanson, M., Edelman, A., and Ollero, M. 2009.

Eicosanoid Release Is Increased by Membrane Destabilization and CFTR Inhibition in Calu-3 Cells. PLoS One 4(10): e7116.

Bryant, D.M., and Stow, J.L. 2004. The ins and outs of E-cadherin trafficking. Trends in Cell Biology 14(8): 427-434. doi:10.1016/j.tcb.2004.07.007.

Corvera, S., DiBonaventura, C., and Shpetner, H.S. 2000. Cell confluence-dependent remodeling of endothelial membranes mediated by cholesterol. J Biol Chem 275(40): 31414-21.

Dinic, J., Ashrafzadeh, P., and Parmryd, I. 2013. Actin filaments attachment at the plasma membrane in live cells cause the formation of ordered lipid domains. Biochimica et Biophysica Acta (BBA) - Biomembranes 1828(3): 1102-1111. doi:10.1016/j.bbamem.2012.12.004.

Drees, F., Pokutta, S., Yamada, S., Nelson, W.J., and Weis, W.I. 2005. $\alpha$-Catenin Is a Molecular Switch that Binds E-Cadherin- $\beta$-Catenin and Regulates Actin-Filament Assembly. Cell 123(5): 903-915. doi:10.1016/j.cell.2005.09.021.

Evans, W.H. 1978. Preparation and Characterisation of Mammalian Plasma membranes. In NorthHolland Publishing. T.S Work and E. Work, Amsterdam.

Falsey, R.R., Marron, M.T., Gunaherath, G.M.K.B., Shirahatti, N., Mahadevan, D., Gunatilaka, A.A.L., and Whitesell, L. 2006. Actin microfilament aggregation induced by withaferin A is mediated by annexin II. Nature Chemical Biology 2(1): 33-38. doi:10.1038/nchembio755.

Filipenko, N.R., and Waisman, D.M. 2001. The C Terminus of Annexin II Mediates Binding to Factin. J. Biol. Chem. 276(7): 5310-5315. doi:10.1074/jbc.M009710200. 
Gabel, M., Delavoie, F., Royer, C., Tahouly, T., Gasman, S., Bader, M.-F., Vitale, N., and ChasserotGolaz, S. 2019. Phosphorylation cycling of Annexin A2 Tyr23 is critical for calcium-regulated exocytosis in neuroendocrine cells. Biochim Biophys Acta Mol Cell Res. doi:10.1016/j.bbamcr.2018.12.013.

Gerke, V., and Moss, S.E. 2002. Annexins: from structure to function. Physiol Rev 82(2): 331-71.

Gerke, V., and Weber, K. 1984. Identity of p36K phosphorylated upon Rous sarcoma virus transformation with a protein purified from brush borders; calcium-dependent binding to nonerythroid spectrin and F-actin. Embo J 3(1): 227-33.

Gokhale, N.A., Abraham, A., Digman, M.A., Gratton, E., and Cho, W. 2005. Phosphoinositide specificity of and mechanism of lipid domain formation by annexin A2-p11 heterotetramer. $\mathrm{J}$ Biol Chem 280(52): 42831-40.

Graauw, M. de, Tijdens, I., Smeets, M.B., Hensbergen, P.J., Deelder, A.M., and Water, B. van de. 2008. Annexin A2 Phosphorylation Mediates Cell Scattering and Branching Morphogenesis via Cofilin Activation. Molecular and Cellular Biology 28(3): 1029-1040. doi:10.1128/MCB.01247-07.

Grieve, A.G., Moss, S.E., and Hayes, M.J. 2012. Annexin A2 at the Interface of Actin and Membrane Dynamics: A Focus on Its Roles in Endocytosis and Cell Polarization. Research article. doi:10.1155/2012/852430.

Grindheim, A.K., Hollås, H., Ramirez, J., Saraste, J., Travé, G., and Vedeler, A. 2014. Effect of Serine Phosphorylation and Ser25 Phospho-Mimicking Mutations on Nuclear Localisation and Ligand Interactions of Annexin A2. Journal of Molecular Biology 426(13): 2486-2499. doi:10.1016/j.jmb.2014.04.019.

Grindheim, A.K., Saraste, J., and Vedeler, A. 2017. Protein phosphorylation and its role in the regulation of Annexin A2 function. Biochimica et Biophysica Acta (BBA) - General Subjects 1861(11, Part A): 2515-2529. doi:10.1016/j.bbagen.2017.08.024.

Hansen, M.D.H., Ehrlich, J.S., and Nelson, W.J. 2002. Molecular Mechanism for Orienting Membrane and Actin Dynamics to Nascent Cell-Cell Contacts in Epithelial Cells. J. Biol. Chem. 277(47): 45371-45376. doi:10.1074/jbc.M207747200.

Harder, T., and Simons, K. 1997. Caveolae, DIGs, and the dynamics of sphingolipid-cholesterol microdomains. Curr Opin Cell Biol 9(4): 534-42.

Hayes, M.J., Rescher, U., Gerke, V., and Moss, S.E. 2004. Annexin-Actin Interactions. Traffic 5(8): 571-576. doi:10.1111/j.1600-0854.2004.00210.x.

Hayes, M.J., Shao, D., Bailly, M., and Moss, S.E. 2006. Regulation of actin dynamics by annexin 2. The EMBO Journal 25(9): 1816-1826. doi:10.1038/sj.emboj.7601078.

Hayes, M.J., Shao, D.-M., Grieve, A., Levine, T., Bailly, M., and Moss, S.E. 2009. Annexin A2 at the interface between F-actin and membranes enriched in phosphatidylinositol 4,5,-bisphosphate. Biochimica et Biophysica Acta (BBA) - Molecular Cell Research 1793(6): 1086-1095. doi:10.1016/j.bbamcr.2008.10.007.

Hein, Z., Schmidt, S., Zimmer, K.-P., and Naim, H.Y. 2011. The dual role of annexin II in targeting of brush border proteins and in intestinal cell polarity. Differentiation 81(4): 243-252. doi:10.1016/j.diff.2011.01.009.

Heyraud, S., Jaquinod, M., Durmort, C., Dambroise, E., Concord, E., Schaal, J.P., Huber, P., and Gulino-Debrac, D. 2008. Contribution of Annexin 2 to the Architecture of Mature Endothelial Adherens Junctions. Molecular and Cellular Biology 28(5): 1657-1668. doi:10.1128/MCB.00695-07.

Illien, F., Piao, H.R., Coue, M., di Marco, C., and Ayala-Sanmartin, J. 2012. Lipid organization regulates annexin $\mathrm{A} 2 \mathrm{Ca}(2+)$-sensitivity for membrane bridging and its modulator effects on membrane fluidity. Biochimica et biophysica acta 1818(11): 2892-900.

Johnsson, N., Nguyen Van, P., Soling, H.D., and Weber, K. 1986. Functionally distinct serine phosphorylation sites of $\mathrm{p} 36$, the cellular substrate of retroviral protein kinase; differential inhibition of reassociation with p11. Embo J 5(13): 3455-60.

Jones, P.G., Moore, G.J., and Waisman, D.M. 1992. A nonapeptide to the putative F-actin binding site of annexin-II tetramer inhibits its calcium-dependent activation of actin filament bundling. J Biol Chem 267(20): 13993-7. 
Jost, M., and Gerke, V. 1996. Mapping of a regulatory important site for protein kinase C phosphorylation in the N-terminal domain of annexin II. Biochim Biophys Acta 1313(3): 2839.

Khanna, N.C., Tokuda, M., Chong, S.M., and Waisman, D.M. 1986. Phosphorylation of p36 in vitro by protein kinase C. Biochem Biophys Res Commun 137(1): 397-403.

Lamaziere, A., Burlina, F., Wolf, C., Chassaing, G., Trugnan, G., and Ayala-Sanmartin, J. 2007. Nonmetabolic membrane tubulation and permeability induced by bioactive peptides. PLoS ONE 2: e201.

Lee, D.B.N., Jamgotchian, N., Allen, S.G., Kan, F.W.K., and Hale, I.L. 2004. Annexin A2 heterotetramer: role in tight junction assembly. American Journal of Physiology-Renal Physiology. doi:10.1152/ajprenal.00175.2003.

Liao, L., Zheng, B., Yi, B., Liu, C., Chen, L., Zeng, Z., and Gao, J. 2017. Annexin A2-modulated proliferation of pulmonary arterial smooth muscle cells depends on caveolae and caveolin-1 in hepatopulmonary syndrome. Experimental Cell Research 359(1): 266-274. doi:10.1016/j.yexcr.2017.07.020.

López-Rodríguez, J.C., Martínez-Carmona, F.J., Rodríguez-Crespo, I., Lizarbe, M.A., and Turnay, J. 2018. Molecular dissection of the membrane aggregation mechanisms induced by monomeric annexin A2. Biochimica et Biophysica Acta (BBA) - Molecular Cell Research 1865(6): 863873. doi:10.1016/j.bbamcr.2018.03.010.

Ma, A.S., Bystol, M.E., and Tranvan, A. 1994. In vitro modulation of filament bundling in F-actin and keratins by annexin II and calcium. In Vitro Cell Dev Biol Anim 30A(5): 329-35.

Maniti, O., Blanchard, E., Trugnan, G., Lamaziere, A., and Ayala-Sanmartin, J. 2012. Metabolic energy-independent mechanism of internalization for the cell penetrating peptide penetratin. The international journal of biochemistry \& cell biology 44(6): 869-75.

Martin-Belmonte, F., Gassama, A., Datta, A., Yu, W., Rescher, U., Gerke, V., and Mostov, K. 2007. PTEN-mediated apical segregation of phosphoinositides controls epithelial morphogenesis through Cdc42. Cell 128(2): 383-97.

Merrifield, C.J., Rescher, U., Almers, W., Proust, J., Gerke, V., Sechi, A.S., and Moss, S.E. 2001. Annexin 2 has an essential role in actin-based macropinocytic rocketing. Current Biology 11(14): 1136-1141. doi:10.1016/S0960-9822(01)00321-9.

Miyahara, A., Nakanishi, N., Ooka, T., Hayashi, T., Sugimoto, N., and Tobe, T. 2009. Enterohemorrhagic Escherichia coli effector EspL2 induces actin microfilament aggregation through annexin 2 activation. Cell. Microbiol. 11(2): 337-350. doi:10.1111/j.14625822.2008.01256.x.

Monastyrskaya, K., Babiychuk, E.B., and Draeger, A. 2009. The annexins: spatial and temporal coordination of signaling events during cellular stress. Cell Mol Life Sci 66(16): 2623-42.

Monastyrskaya, K., Babiychuk, E.B., Hostettler, A., Rescher, U., and Draeger, A. 2007. Annexins as intracellular calcium sensors. Cell Calcium 41(3): 207-19.

Munera, D., Martinez, E., Varyukhina, S., Mahajan, A., Ayala-Sanmartin, J., and Frankel, G. 2012. Recruitment and membrane interactions of host cell proteins during attachment of enteropathogenic and enterohaemorrhagic Escherichia coli. The Biochemical journal 445(3): 383-92.

Murata, M., Peränen, J., Schreiner, R., Wieland, F., Kurzchalia, T.V., and Simons, K. 1995. VIP/caveolin is a cholesterol-binding protein. Procs Natl Acad Sci USA 92: 10339-10343.

Oliferenko, S., Paiha, K., Harder, T., Gerke, V., Schwarzler, C., Schwarz, H., Beug, H., Gunthert, U., and Huber, L.A. 1999. Analysis of CD44-containing lipid rafts: Recruitment of annexin II and stabilization by the actin cytoskeleton. J Cell Biol 146(4): 843-54.

Regnouf, F., Sagot, I., Delouche, B., Devilliers, G., Cartaud, J., Henry, J.P., and Pradel, L.A. 1995. "In vitro" phosphorylation of annexin 2 heterotetramer by protein kinase C. Comparative properties of the unphosphorylated and phosphorylated annexin 2 on the aggregation and fusion of chromaffin granule membranes. J Biol Chem 270(45): 27143-50.

Rescher, U., and Gerke, V. 2004. Annexins--unique membrane binding proteins with diverse functions. J Cell Sci 117(Pt 13): 2631-9. 
Rescher, U., Ludwig, C., Konietzko, V., Kharitonenkov, A., and Gerke, V. 2008. Tyrosine phosphorylation of annexin A2 regulates Rho-mediated actin rearrangement and cell adhesion. Journal of Cell Science 121(13): 2177-2185. doi:10.1242/jcs.028415.

Rescher, U., Ruhe, D., Ludwig, C., Zobiack, N., and Gerke, V. 2004. Annexin 2 is a phosphatidylinositol $(4,5)$-bisphosphate binding protein recruited to actin assembly sites at cellular membranes. Journal of Cell Science 117(16): 3473-3480. doi:10.1242/jcs.01208.

Smart, E.J., Rose, R.A.D., and Farber, S.A. 2004. Annexin 2-caveolin 1 complex is a target of ezetimibe and regulates intestinal cholesterol transport. PNAS 101(10): 3450-3455. doi:10.1073/pnas.0400441101.

Su, S.-C., Maxwell, S.A., and Bayless, K.J. 2010. Annexin 2 Regulates Endothelial Morphogenesis by Controlling AKT Activation and Junctional Integrity. J. Biol. Chem. 285(52): 40624-40634. doi:10.1074/jbc.M110.157271.

Takenawa, T., and Itoh, T. 2001. Phosphoinositides, key molecules for regulation of actin cytoskeletal organization and membrane traffic from the plasma membrane. Biochimica et Biophysica Acta (BBA) - Molecular and Cell Biology of Lipids 1533(3): 190-206. doi:10.1016/S13881981(01)00165-2.

Taylor, J.R., Fernandez, D.J., Thornton, S.M., Skeate, J.G., Lühen, K.P., Da Silva, D.M., Langen, R., and Kast, W.M. 2018. Heterotetrameric annexin A2/S100A10 (A2t) is essential for oncogenic human papillomavirus trafficking and capsid disassembly, and protects virions from lysosomal degradation. Sci Rep 8(1): 11642. doi:10.1038/s41598-018-30051-2.

Uittenbogaard, A., Everson, W.V., Matveev, S.V., and Smart, E.J. 2002. Cholesteryl Ester Is Transported from Caveolae to Internal Membranes as Part of a Caveolin-Annexin II LipidProtein Complex. J. Biol. Chem. 277(7): 4925-4931. doi:10.1074/jbc.M109278200.

Vogelmann, R., and Nelson, W.J. 2004. Fractionation of the Epithelial Apical Junctional Complex: Reassessment of Protein Distributions in Different Substructures. MBoC 16(2): 701-716. doi:10.1091/mbc.e04-09-0827.

Yamada, A., Irie, K., Hirota, T., Ooshio, T., Fukuhara, A., and Takai, Y. 2005a. Involvement of the annexin II-S100A10 complex in the formation of E-cadherin-based adherens junctions in Madin-Darby canine kidney cells. J Biol Chem 280(7): 6016-27.

Yamada, S., Pokutta, S., Drees, F., Weis, W.I., and Nelson, W.J. 2005b. Deconstructing the CadherinCatenin-Actin Complex. Cell 123(5): 889-901. doi:10.1016/j.cell.2005.09.020.

Zakrzewicz, D., Didiasova, M., Zakrzewicz, A., Hocke, A.C., Uhle, F., Markart, P., Preissner, K.T., and Wygrecka, M. 2014. The interaction of enolase-1 with caveolae-associated proteins regulates its subcellular localization. Biochem. J. 460(2): 295-307. doi:10.1042/BJ20130945.

Zobiack, N., Rescher, U., Laarmann, S., Michgehl, S., Schmidt, M.A., and Gerke, V. 2002. Cellsurface attachment of pedestal-forming enteropathogenic E. coli induces a clustering of raft components and a recruitment of annexin 2. Journal of Cell Science 115(1): 91-98.

\section{Figure legends}



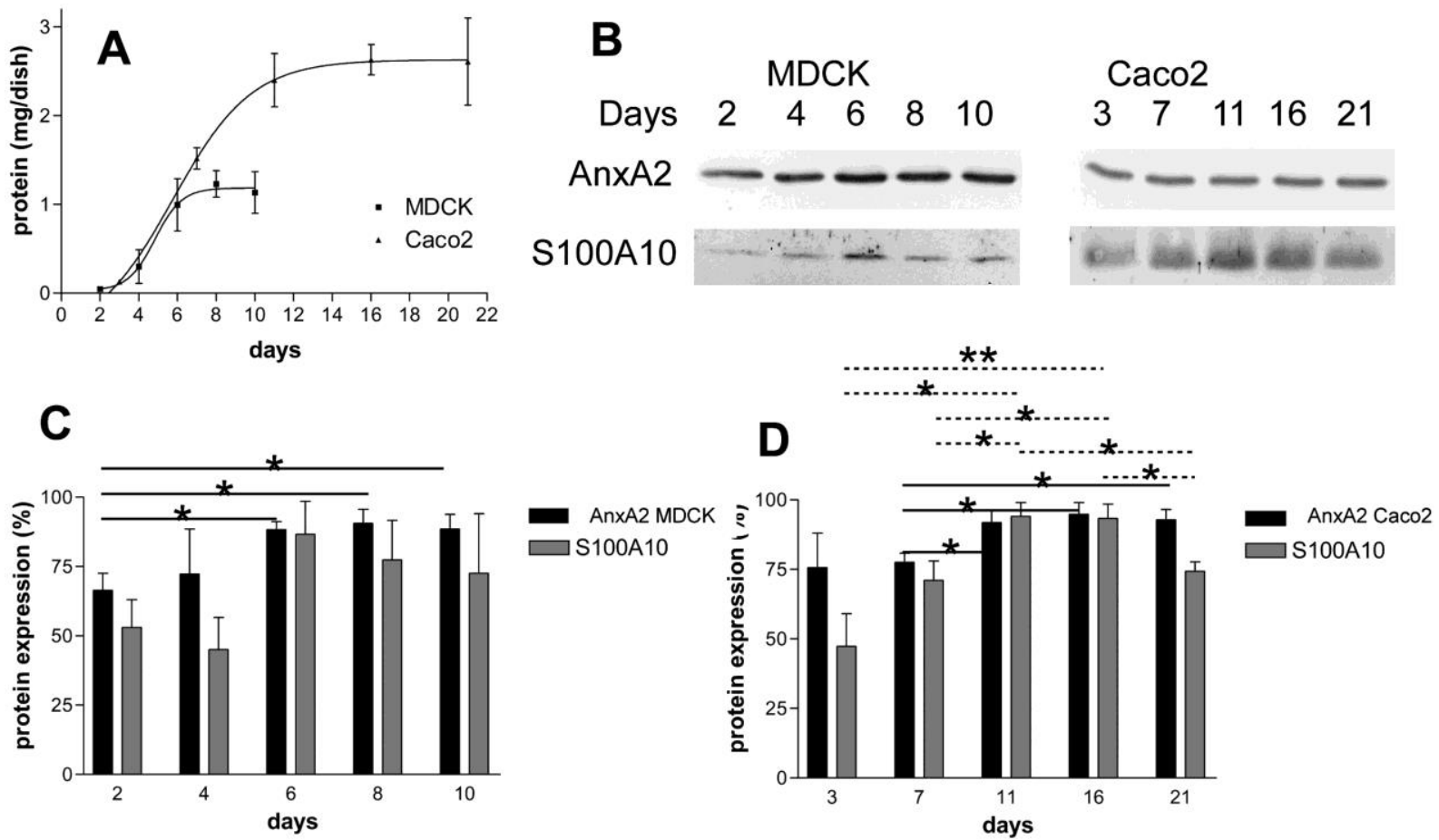

Figure 1. Annexin A2 and S100A10 expression during epithelial cell differentiation.

A; Kinetics of cell culture growth of MDCK and Caco2 cell lines followed by total protein expression as a function of time. B; Expression of annexin A2 and S100A10 by western blot. Each well contains contained $7.5 \mu \mathrm{g}$ of MDCK extracts and $15 \mu \mathrm{g}$ of Caco 2 extracts. Quantitative analysis of protein expression for MDCK cells (C) and Caco2 cells (D). Gel quantification was performed by normalizing the bands intensities in percent; the strongest band for each gel being the $100 \%$ of expression. This normalization allows the statistical comparison of different experiments. Notice the slight increase in annexin A2 and S100A10 expression during cell contacts formation. Means \pm SEM from 3 to 4 experiments. $*=\mathrm{P}<0.05, * *=\mathrm{P}<0.01$, continuous and dotted lines for AnxA2 and S100A10 respectively.

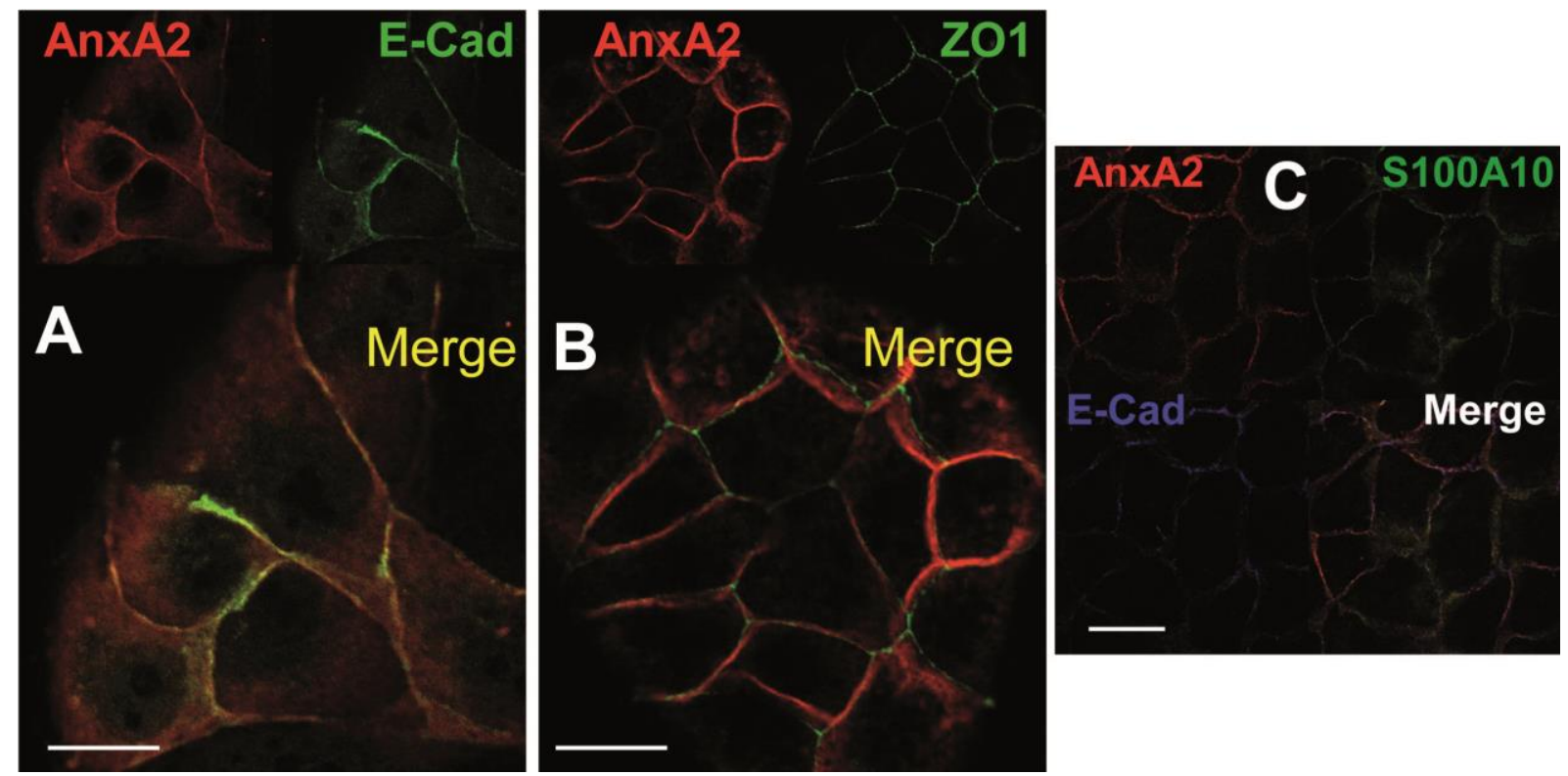

Figure 2. Annexin A2, E-cadherin, ZO1 and S100A10 expression in MDCK cells.

Confocal images of MDCK cells after four days in culture and plated at a low density ( 5000 cells per well). Annexin A2 and E-cadherin are co-localized in the lateral membrane (A). Annexin A2 and the 
tight junction marker ZO1 does not co-localize (B). Triple labelling of MDCK cells showing colocalization of AnxA2, S100A10 and E-Cadherin (C). Bars, $20 \mu \mathrm{m}$.

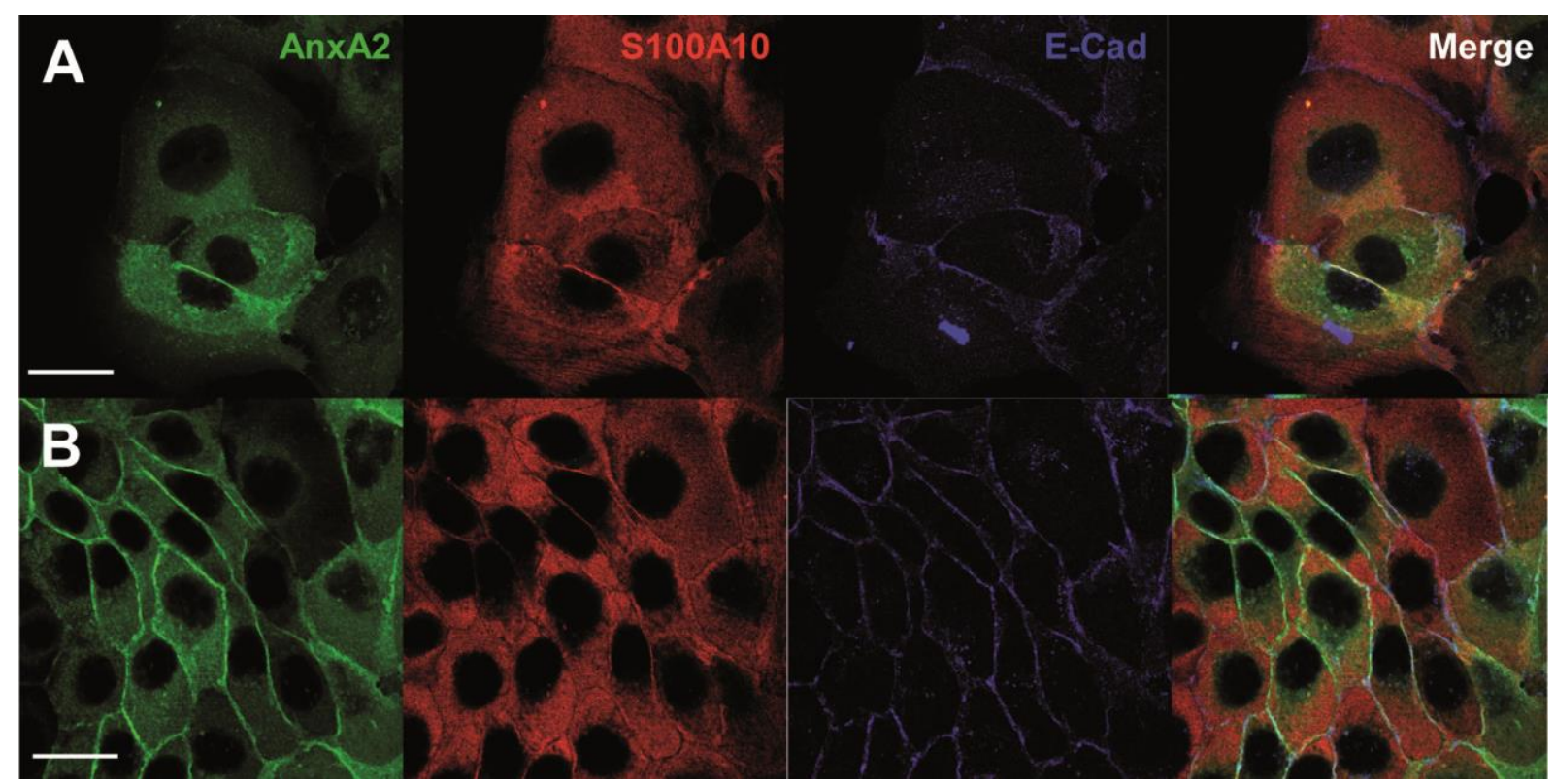

Figure 3. AnxA2-GFP, S100A10 and E-cadherin expression in MDCK cells.

Confocal images of MDCK cells after 3 days in culture plated at 5000 (A) and 20000 cells per well (B). AnxA2-GFP, S100A10 and E-cadherin are co-localized in the lateral membranes. Bars, $20 \mu \mathrm{m}$.

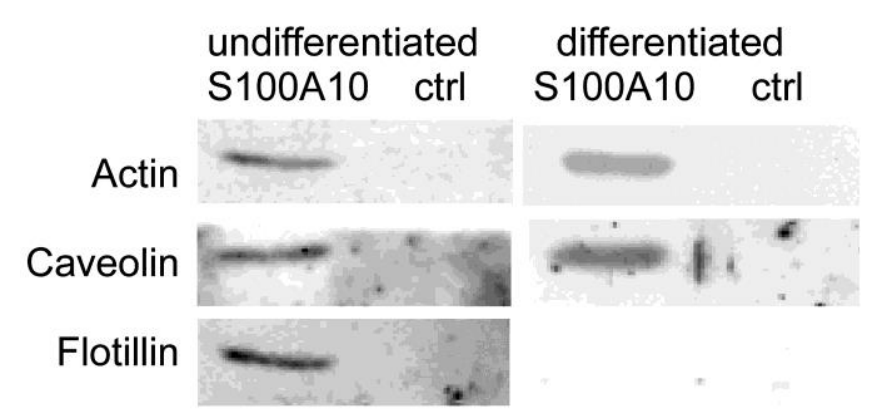

Figure 4. S100A10-AnxA2 binding proteins in undifferentiated and differentiated epithelial cells.

Western blots of cellular fractions from undifferentiated and differentiated epithelial MDCK cells eluted from S100A10 affinity (S100A10) and control (ctrl) columns. 

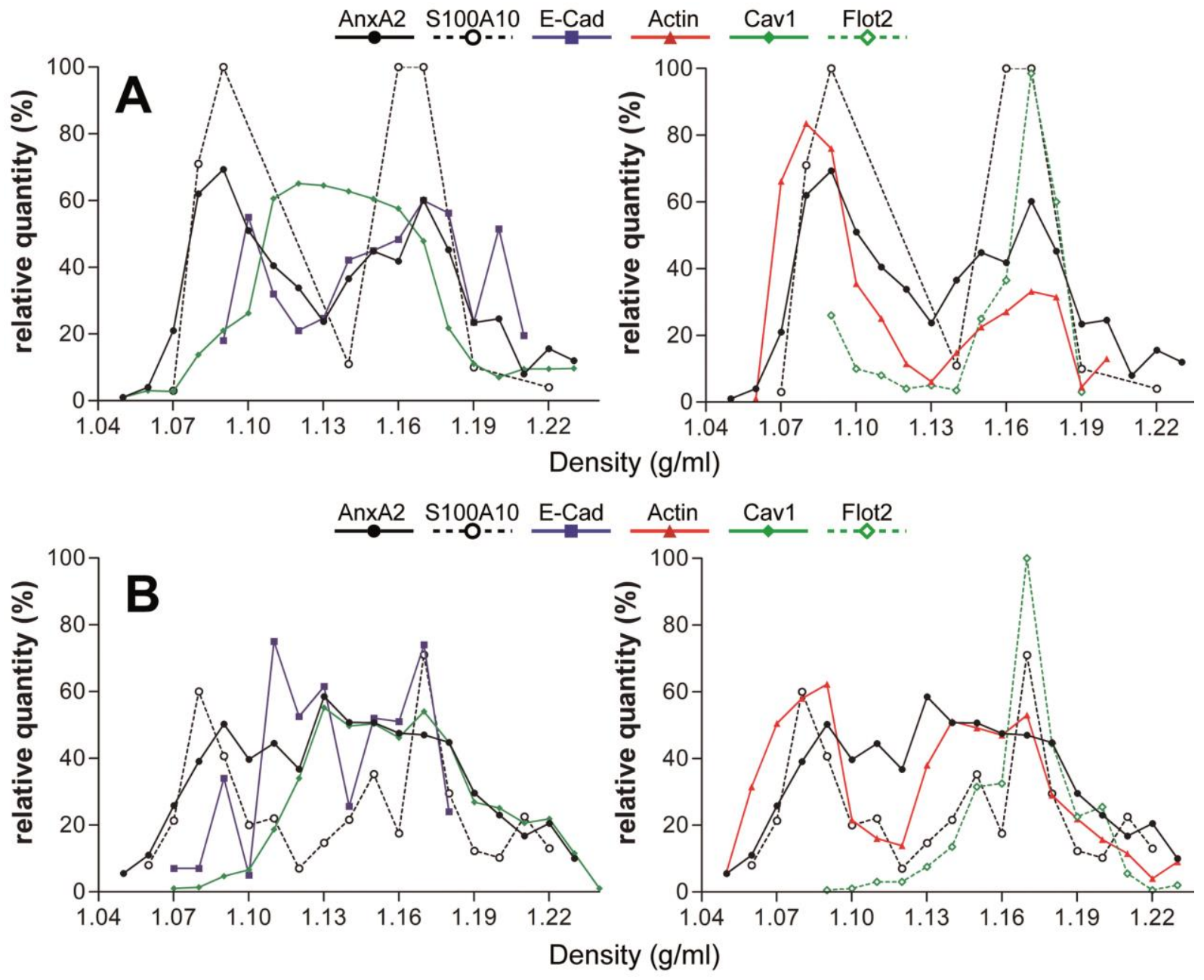

Figure 5. Protein profiles on sucrose density gradients in undifferentiated and differentiated MDCK cells.

(A), non-differentiated cells. (B), differentiated cells. Annexin A2 (black continuous line •), S100A10 (black dotted line $\circ$ ), actin (red $\mathbf{\Delta}$ ), E-cadherin (blue $\mathbf{-}$ ), caveolin 1 (green continuous line $\downarrow$ ) and flotillin 2 (green dotted line $\diamond$ ). The profiles are means of 2 to 6 independent experiments. 


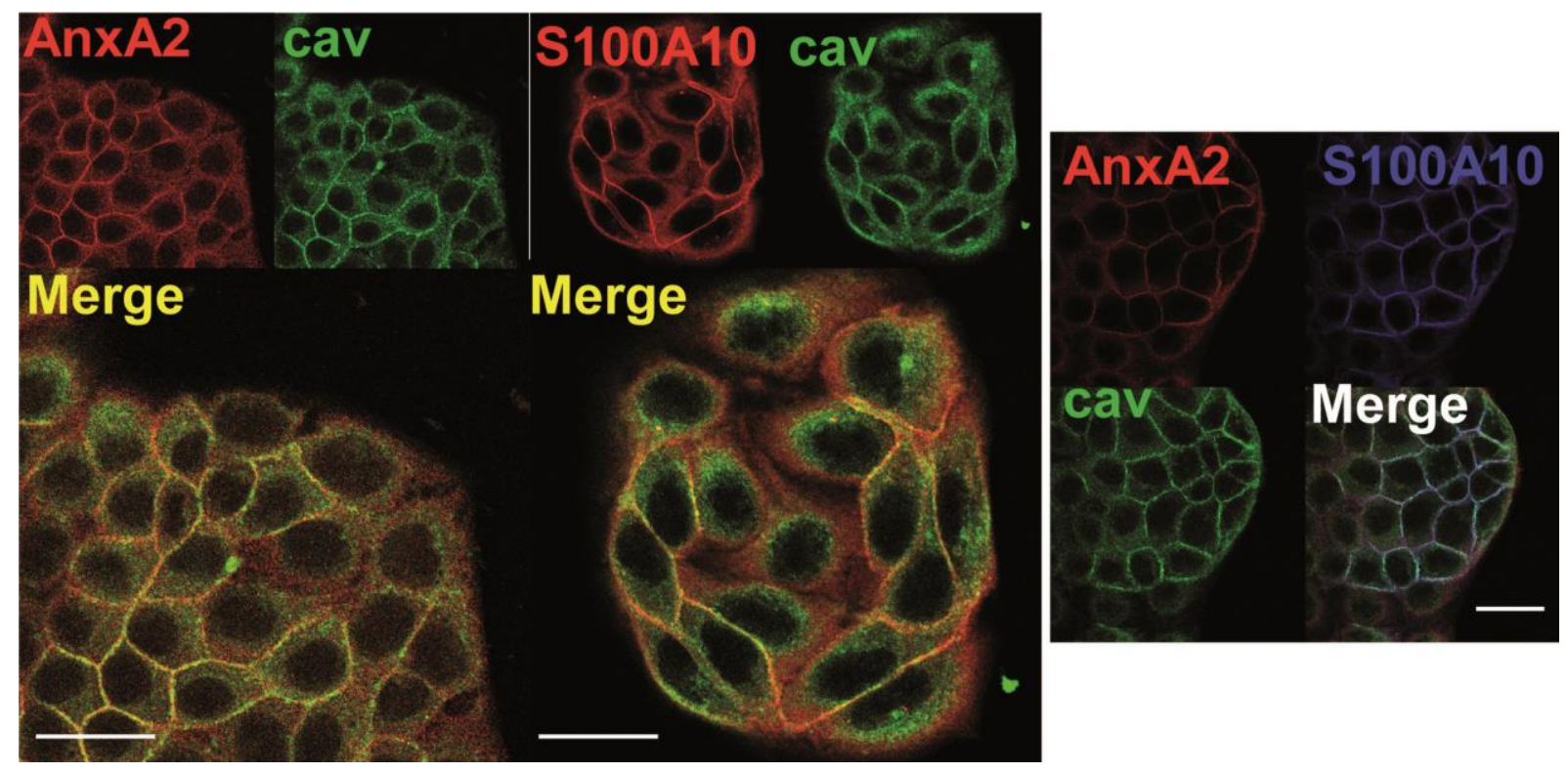

Figure 6. Annexin A2, S100A10 and caveolin expression in MDCK cells.

Confocal images of MDCK cells after four days in culture and plated at a low density ( 5000 cells per well). AnxA2, S100A10 and caveolin 1 are clearly co-localized in the lateral membranes involved in cell contacts. Bars, $20 \mu \mathrm{m}$.
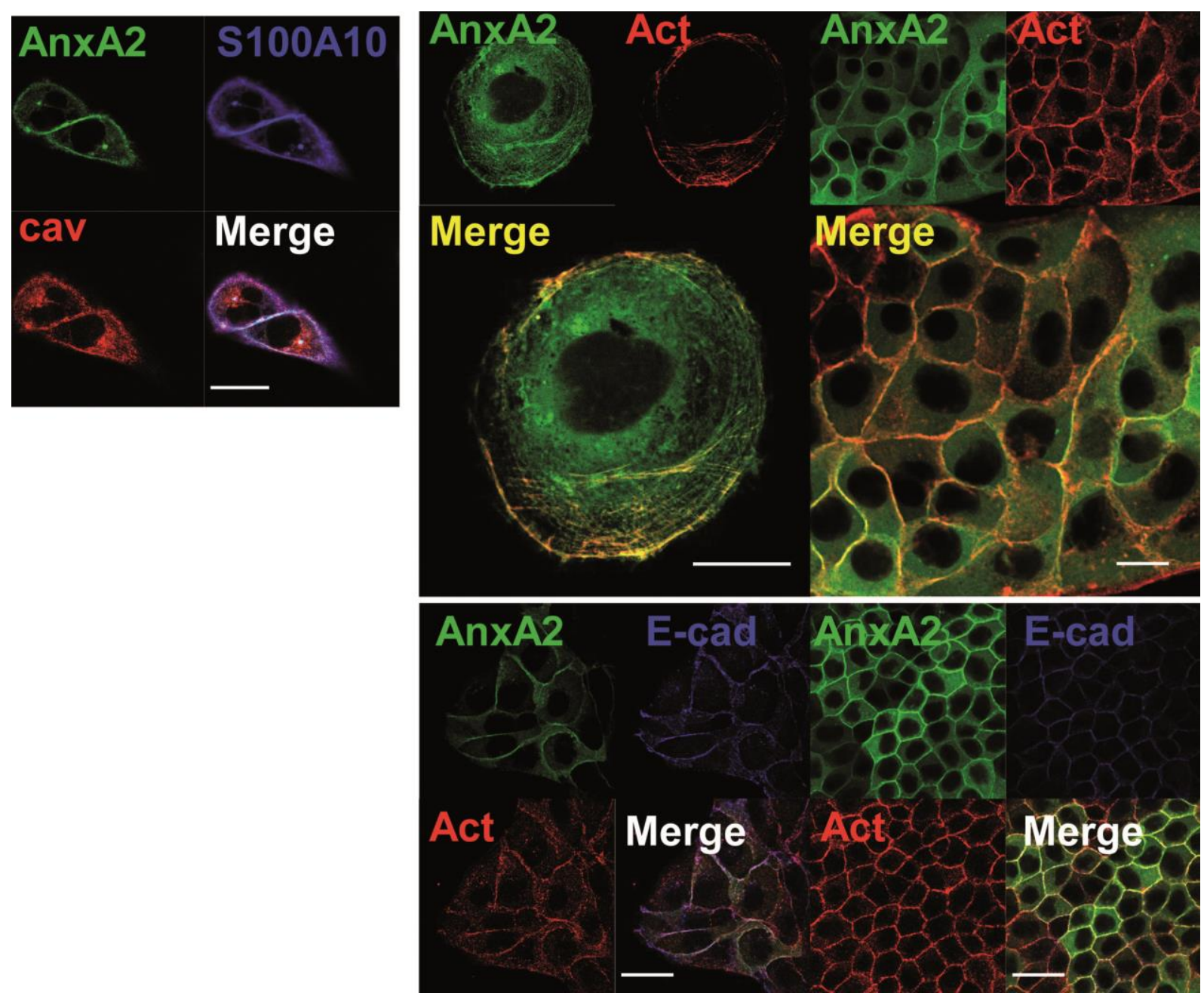
Figure 7. Annexin A2, S100A10, actin, E-cadherin and caveolin 1 expression in AnxA2-GFP MDCK cells.

Confocal images of AnxA2-GFP transfected MDCK cells after four days in culture plated at different densities. AnxA2, S100A10 and caveolin 1 clearly co-localize in lateral membranes involved in cell contacts (top). Actin and AnxA2 co-localizes in cell membranes of isolated cells and in contacts (middle). They co-localize with E-cadherin (bottom). Bars, $20 \mu \mathrm{m}$.

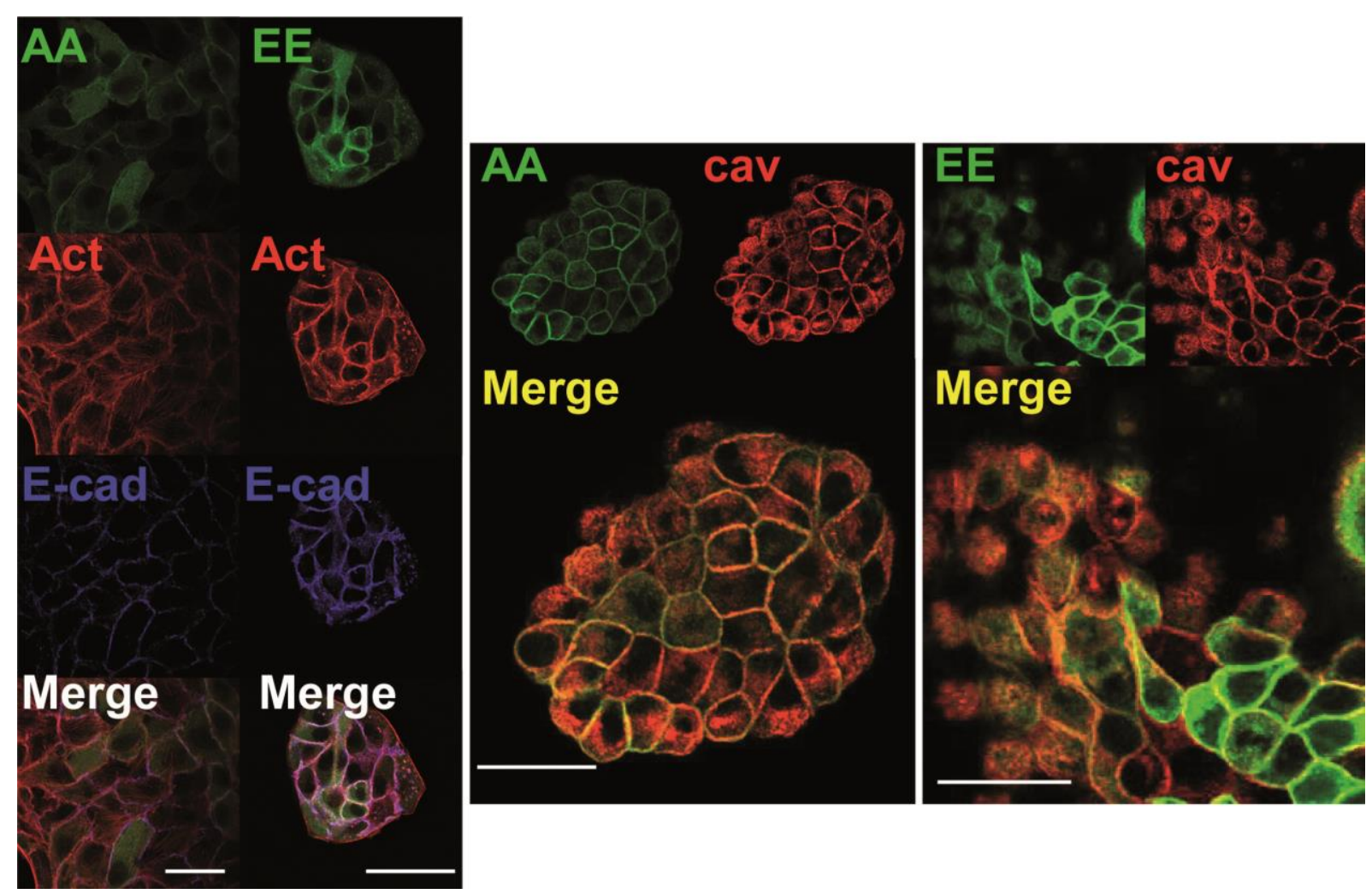

Figure 8. Localization of E-cadherin, caveolin 1 and actin in AnxA2-GFP phosphorylation mutants.

The cellular localization of the AnxA2 phosphorylation mutants S11A-S25A (AA) and S11E-S25E (EE) is similar to the wild type protein. The cellular localization of actin, E-cadherin and caveolin was not modified by the presence of mutant proteins. Bars, $20 \mu \mathrm{m}$. 